\title{
A Preliminary Study on the Use of Ultrasound for Obtaining Pulsatile Release
}

Yelda KOMESLİ, Emel Öykü ÇETİN, Levent KIRILMAZ, Evren GÜNDOĞDU

\begin{abstract}
In this study, the controlled release tablet of diltiazem hydrochloride was developed. The controlled release tablets were prepared with ethyl cellulose by changing the ratio of diltiazem hydrochloride and the in vitro release studies were carried out by using an ultrasonic water bath. According to release results, a new equation was developed that can be used to estimate the release of drug as a function of time and drug content in the formulation. In addition, the effect of ultrasound on the release of diltiazem hydrochloride from controlled
\end{abstract}

release dosage forms and relationships between release rate constants and drug contents were investigated. This study showed that the developed equation can successfully be used to estimate the effect of ultrasound on the release of drug from the formulations prepared with different concentrations of diltiazem hydrochloride. It was concluded that ultrasound has a very important effect on the release of drug and increases drug release obviously.

Keywords: ultrasound; controlled release; pulsatile release
Yelda Komesli, Emel Öykü Çetin, Levent Kırılmaz

Ege University, Faculty of Pharmacy, Department of Biopharmaceutics and Pharmacokinetics, 35100 Bornova-İzmir, Turkey

Evren Gündoğdu

Ege University, Faculty of Pharmacy, Department of Radiopharmacy,

35100 Bornova-İzmir, Turkey

Corresponding author:

Yelda Komesli

Çankaya Mah. 155 sk. No:33 Daire: 935280 Konak, Izmir TURKEY

Tel : +905055718201

Fax : +902322445576

E-Mail : ykomesli@sgk.gov.tr ykomesli@gmail.com

\section{INTRODUCTION}

Plasma concentrations of drug depend on the frequency of administration. In conventional drug release, the blood concentration of the drug increases, reaches a peak and falls after the drug administration. For these reasons, we plan to work responsive systems in our study. We have examined the response of different drug content of the polymeric tablets to the ultrasound. Polymeric controlled drug delivery systems were used to obtain controlled drug delivery. In this study, the relationship between the release rate constants, ultrasound and drug contents were investigated. It is found that the ultrasound has a very important effect on the release of drug and increases drug release clearly.

The intensive works on responsive implantable polymeric drug systems had begun in 1980's. These systems are categorized in two different groups:

1. Feed-back Controlled Systems $(1,2)$

a. Electrically Controlled Systems $(3,4,5)$

b. Chemically Responsive Systems $(6,7)$ 


\section{Modulatable externally Systems}

a. Magnetically stimulated Systems (8)

b. Ultrasound Systems $(9,10)$

The recent researches into the area of controlled drug delivery have been focused on the development of systems which result in either zero-order drug release or a drug release profile which is a simple function of time. This approach has been based on the assumption that optimal clinical outcomes may be achieved by maintaining a constant drug plasma concentration and that drug concentration-effect relationships do not vary overtime. However, it is apparent that varying or pulsed drug release is therapeutically preferable with some drugs, and that there are a number of clinical situations which may benefit from a more responsive approach to drug delivery $(9,10)$.

The use of externally applied ultrasound to trigger release from polymeric delivery devices has been proposed as a means of modulating drug release from implants. These relatively simple devices consist of a polymer and drug and are designed for subcutaneous implantation. A basal level of drug release occurs as a result of diffusion which may be augmented by exposing the area of skin above the implant to therapeutic levels of ultrasound. It has been demonstrated both in vivo and in vitro that release can be significantly enhanced using ultrasound $(11,12)$.

Recently, liposomes in which contains drugs are being used in the drug distribution increased by ultrasound and drug release controlled by ultrasound. Liposomal ultrasound based drug and gen transportation in vivo applications are utilized in the treatment of cardiac disease, stroke and tumor therapy (13). Acoustic energy collection enabled with ultrasound is utilized to activate the drug and gene distribution, and to make changes in tissue transitions (14). It is investigated that the effects of microbubles to increasing drug release with ultrasound (15). The other study focuses, characterization and synthesis of polymeric microcapsules on lipophilic drug transportation triggered by ultrasound. Microcapsules consist of a drug-parting depot including various amounts of hexadecane oil with a separate gaseous phase, and a fluorinated end-capped poly (L-lactic acid) shell were made pre-mix membrane emulsification. Under the high diagnostic pressure, microcapsule crashes and gas inside it and lipophilic drug are released (16).

The use of AP-1-conjugated liposomes which include cytotoxic agents followed by HIFU (high frequencies of ultrasound ) pulse, in the treatment of brain tumor in such a improved way for the distribution of the drugs to the targeted area (17).
In another study, the drug release, loaded to titanium nanotubes from micelles, was enhanced by the application of ultrasound. The effects of ultrasound on the drug release from micelles by applying ultrasound continuously and intermittently. Ultrasound significantly increased the release of drug. The acoustic power which affects the depth of nanotubes describes increased release from polymeric micelles. Long and short waves of ultrasound and 1, 5, 10, 15 pulses per minute applications were examined. The best results were obtained by 15 pulse application in 5 minutes. A linear correlation was found between the number of pulses per minute and the generated thermal energy. Short pulses indicated the great energy and acoustic power. Local drug delivery systems are used in bone infections, fracture healing, secondary bone cancer, tissue repair and reducing inflammation. This type of drug delivery systems can be applied in orthopedic or coronary stents (18-20).

To evaluate the effect of magnetically stimulated drug release, dopamine conjugated iron oxide nanoparticles were designed. Loaded polymeric micelles as drug carriers with titanium nanotube arrays were used to provide stimulusresponse drug delivery system. Magnetic stimulated drug release was obtained by adding magnetic nanoparticles in the bottom of nanotubes (21).

Recent studies show that, the cavitation generated by the ultrasound waves caused to cellular incorporation of macromolecules up to $28 \mathrm{~nm}$. This reversible effect is the result of injury of the plasma membrane created by ultrasound and providing passage halls self-re-sealed in a short time by the cells. Thus non-invasively focused ultrasound can be used for drug and gene delivery to targeted cancer cells and tissues, minimizing side effects, enhancing therapeutic effects, lowering doses of drugs (22). Acoustically active drugs were developed from encapsulated liposomes which can be activated with ultrasound waves. Due to air contents, liposomes could response ultrasound activity and release drugs. The liposomes were made phosphatidylcholine, phosphatidylethanolamine, phosphatidylglycerol, cholesterol and mannitol. After sonication, lyophilization and rehydration, a hydrating lipid film added in order to make liposomes acoustically active. 1 $\mathrm{MHz}$ ultrasound at $2 \mathrm{~W} / \mathrm{cm} 2$ for $10 \mathrm{~s}$ applied for efficient Ultrasound-triggered release (23).

In another study Doxorubicin activity was enhanced with ultrasound and no effect was observed near tissues without ultrasound in rats (24).

For a long time ultrasound has been applied at hospitals. However, FDA recently, approved the use of Exogen (Exogen is a registered trademark of Bioventus LLC, 
Durham, NC 27703 USA. Product No. 81079936 Rev 02012-05) for bone fractures, because of its ultrasonic effects. It can be easily applied by patients at their houses (Figure 1).

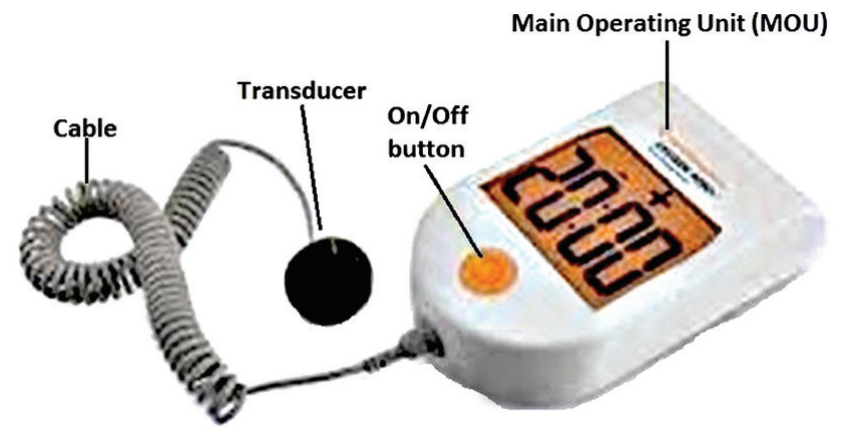

Figure 1. Photograph and application of Exogen.

(Exogen is a registered trademark of Bioventus LLC, 4721 Emperor Blvd, Suite 100, Durham, NC 27703 USA. Product No. 81079936 Rev 02012-05)

\section{MATERIALS AND METHODS}

\section{MATERIALS}

Diltiazem HCl was supplied from İlsan- İltaş, İstanbulTURKEY. Ethyl cellulose was purchased from Colorcon Limited, İstanbul-TURKEY. Alcohol $\left(96^{\circ}\right)$ was purchased from Tekel, İzmir-TURKEY. UV-Vis spectrophotometer (Shimadzu 1208), ultrasonic water bath (Elma ${ }^{\circledR}$ Transsonic 460/H, $35 \mathrm{kHz}$ ) and oven (Nüve) were also used.

\section{METHODS}

\section{UV SPECTRUM OF DILTIAZEM HCI}

$4 \mathrm{mcg} / \mathrm{ml}$ concentration of diltiazem HCI was dissolved in water and the spectrum of this solution detected from 225 to $350 \mathrm{~nm}$ against the water. The value of maximum absorbance of the solution ( 1 max ) was determined.

\section{DETERMINATION OF THE SATURATION CONCENTRATION}

$5.5 \mathrm{~g}$ of diltiazem $\mathrm{HCI}$ was dissolved in $8 \mathrm{ml}$ distilled water. Mechanical stirring in a water bath at $37^{\circ} \mathrm{C}$ and $150 \mathrm{rev} /$ min stirring speed was kept for 30 minutes. The solution of diltiazem HCI was filtered on paper and $1 \mathrm{ml}$ of the solution was completed to $10 \mathrm{ml}$ with distilled water. Then, $5 \mathrm{ml}$ of this solution also received and complete to $10 \mathrm{ml}$ with distilled water again, absorbance was read in a spectrophotometer and the concentration was calculated with the help of the calibration equation and the saturation concentration (Cs), respectively.

\section{SPECTROPHOTOMETRIC DETERMINATION OF DILTIAZEM HCI}

$100 \mathrm{mg}$ of diltiazem $\mathrm{HCl}$ was dissolved and completed to $50 \mathrm{ml}$ with distilled water water. 10, 20,30, 40 and $50 \mathrm{ml}$ samples were taken from the stock solutions respectively and completed to $5 \mathrm{ml}$ with distilled water. The solutions were measured spectrophotometrically at a wavelength of maximum absorbance. Respectively 4, 8, 12, 16 and $20 \mathrm{mg} /$ $\mathrm{ml}$ corresponding to absorbance measurement is taken place in the graph, by applying regression analysis " $\mathrm{Y}=\mathrm{mX}+\mathrm{n}$ " was obtained in the form of a linear equation. This quantification was used in all equations.

\section{VALIDATION OF ANALYTICAL METHODS Linearity}

6 samples obtained by dilution of the stock solutions and their absorbance were read. The linear equation was obtained from the absorbance values and the corresponding concentrations.

\section{Accuracy}

\section{Repeatibility}

A single $30 \mathrm{mg} / \mathrm{ml}$ concentration of diltiazem HCI solution from calibration stock was prepared and measured 6 different times at $234 \mathrm{~nm}$. The absorbance values obtained from these measurements with the help of the calculated concentration of active substance found. Standard deviation and variation coefficient were calculated. Coefficient of variation of less than $2 \%$ on proving the reproducibility of the method to be used is a valid approach.

\section{Reproducibility}

6 samples were prepared from the stock solution at the same concentration $(30 \mathrm{mg} / \mathrm{ml})$ and measured at $234 \mathrm{~nm}$. Standard deviation and variation coefficient were calculated. Coefficient of variation of less than $2 \%$ on proving the reproducibility of the method to be used is a valid approach.

\section{Specifity}

In order to prove the analytical method was specific to Diltiazem HCL, the spectrum of alcoholic solutions of ethyl cellulose used in studies was taken in the range of 225-350 $\mathrm{nm}$. 


\section{Stability}

$25 \mathrm{~mL}$ diltiazem HCI solution was taken from calibration stock (100 mg diltiazem HCI / 50ml water) completed with $5 \mathrm{ml}$ of water and measured at $234 \mathrm{~nm}$. The amount of the active substance was calculated accordance to the calibration curve. The stock was stored at $37^{\circ} \mathrm{C}$ in oven for 4 hours. Absorbance of the solution was measured with the same dilution and calculated. Standard deviations and relative standard deviations were determined of the results.

\section{PREPARATION OF MATRIX TABLETS}

Controlled release matrix tablets containing 25\%, 50\%, $75 \%$ Diltiazem $\mathrm{HCl}$ were prepared by using ethyl cellulose. Drug contents of tablets were determined practically. Ethyl cellulose was selected as a polymer to obtain controlled release. Diltiazem HCI and ethyl cellulose were mixed thoroughly in accordance with the general rules of mixing in the mortar. The paste was prepared by using alcohol $\left(96^{\circ}\right)$ such as wetting agent. After that, the paste was passed through an injector ( $5 \mathrm{~mm}$ in diameter) by pressing. It was dried for 30 minutes at room temperature. Then, this cylindrical mass was cut into small tablets with the lancet and they were again dried at $40{ }^{\circ} \mathrm{C}$ in an oven during one night. Homogeneity and quantification studies were carried out with the tablets.

\section{QUANTITATIVE DETERMINATION STUDIES IN MATRIX TABLETS}

$25 \%, 50 \%$ and $75 \%$ active ingredients containing matrix tablets were used. The amount of active ingredient in 3 tablets for each formulation were measured. Each tablet dissolved with $100 \mathrm{ml} 96^{\circ}$ etil alcohol in the ultrasonic bain. Appropriate dilutions were done and measured their absorbances at $234 \mathrm{~nm}$ in UV spectktrofotometre. The amount of the diltiazen HCI calculated according to the calibration curve equation.

\section{Homogeneity}

1 tablet for each formulation was divided into three parts and weighed. Then, each part of tablet dissolved with $96^{\circ}$ etil alcohol in the ultrasonic bain. Appropriate dilutions were done and measured their absorbance at $234 \mathrm{~nm}$ in UV spectktrofotometre. The amount of the diltiazem HCI calculated according to the calibration curve equation. Standart deviation and relative standart deviations were calculated.

\section{IN VITRO RELEASE STUDY BY USING APPLYING ULTRASOUND}

Tablets, which have three different drug contents, were placed in $100 \mathrm{ml}$ distilled water and the release studies were carried out by using an ultrasonic water bath $\left(\right.$ Elma ${ }^{\circledR}$ Transsonic $460 / \mathrm{H}, 35 \mathrm{kHz}$ ). For every formulation ultrasound was applied intermittently at pre-determined times. The amounts of drug were determined spectrophotometrically $(234 \mathrm{~nm})$ by applying with or without ultrasound. Release profiles were plotted as a function of time. The temperature of the release medium was remained constant at $37^{\circ} \mathrm{C}$ during the release studies.

\section{RESULTS \\ UV SPECTRUM OF DILTIAZEM HCI}

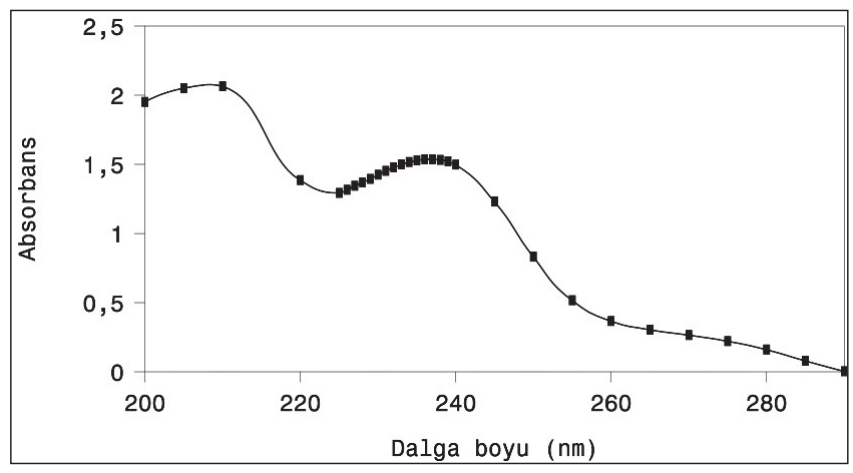

Figure 2: The spectrum of diltiazem HCI in the distilled water

\section{Linearity \\ $\mathrm{r}^{2}=0.9997$ \\ $\mathrm{y}=20.6 \mathrm{x}-3.0 \quad(\mathrm{y}=$ kons.; $\mathrm{x}=$ abs. $)($ Equation 1$)$}

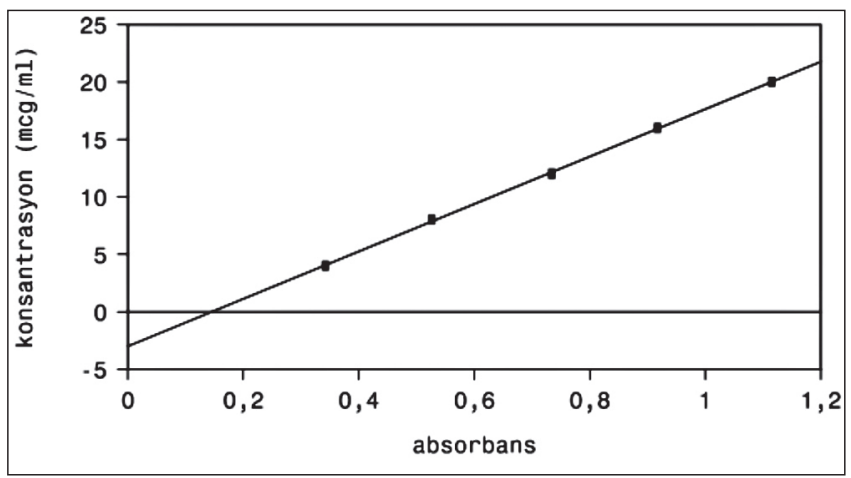

Figure 3: The calibration curve of diltiazem HCI 


\section{Repeatibility}

Table 1.The results of repeatibility

\begin{tabular}{|c|c|c|c|c|}
\hline $\begin{array}{c}\text { Sample } \\
(30 \mu \mathrm{l} / 5 \mathrm{ml})\end{array}$ & Absorbance & $\begin{array}{c}\text { Concentration } \\
(\mu \mathrm{g} / \mathrm{ml})\end{array}$ & $\begin{array}{c}\text { Standart } \\
\text { Deviation }\end{array}$ & $\begin{array}{c}\text { Relative } \\
\text { Standart } \\
\text { Deviation } \\
(\%)\end{array}$ \\
\hline 1 & 0.692 & 11.282 & & \\
\hline 2 & 0.692 & 11.282 & & \\
\cline { 1 - 3 } & 0.693 & 11.302 & \multirow{2}{*}{0.03} & \multirow{2}{*}{0.27} \\
\hline 4 & 0.694 & 11.323 & \\
\hline 5 & 0.693 & 11.302 & & \\
\hline 6 & 0.696 & 11.364 & & \\
\hline
\end{tabular}

\section{Reproducibility}

Table 2.The results of reproducibility

\begin{tabular}{|c|c|c|c|c|}
\hline $\begin{array}{c}\text { Sample } \\
(30 \mu \mathrm{l} / 5 \mathrm{ml})\end{array}$ & Absorbance & $\begin{array}{c}\text { Concentration } \\
(\mu \mathrm{g} / \mathrm{ml})\end{array}$ & $\begin{array}{c}\text { Standart } \\
\text { Deviation }\end{array}$ & $\begin{array}{c}\text { Relative } \\
\text { Standart } \\
\text { Deviation } \\
(\%)\end{array}$ \\
\hline 1 & 0.692 & 11.282 & & \\
\cline { 1 - 3 } 2 & 0.686 & 11.158 & \multirow{2}{*}{0.07} & \multirow{2}{*}{0.65} \\
\cline { 1 - 3 } 3 & 0.684 & 11.117 & \\
\cline { 1 - 3 } 4 & 0.692 & 11.282 & & \\
\hline 5 & 0.685 & 11.137 & & \\
\hline 6 & 0.689 & 11.220 & & \\
\hline
\end{tabular}

\section{Shecifity}

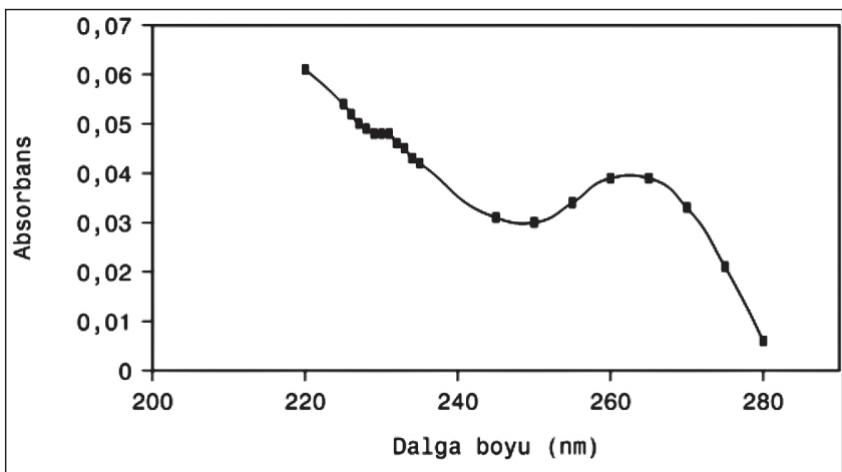

Figure 4: UV spectrum of the ethyl cellulose

\section{Stability}

Table 3.The results of stability

\begin{tabular}{|c|c|c|c|c|}
\hline $\begin{array}{c}\text { Sample } \\
(=10 \mu \mathrm{mcg} / \mathrm{ml})\end{array}$ & $\begin{array}{c}\text { Practical } \\
\text { drug content }\end{array}$ & $\begin{array}{c}\text { Drug content } \\
\text { at } 37^{\circ} \mathrm{C}\end{array}$ & $\begin{array}{c}\text { Standart } \\
\text { Deviation }\end{array}$ & $\begin{array}{c}\text { Relative } \\
\text { Srtandart } \\
\text { Deviation } \\
(\%)\end{array}$ \\
\hline 1 & $9.465 \mathrm{mcg} / \mathrm{ml}$ & $9.444 \mathrm{mcg} / \mathrm{ml}$ & 0.015 & 0.157 \\
\hline
\end{tabular}

\section{THE FORMULATIONS OF MATRIX TABLETS}

Table 4. The formulations of matrix tablets

\begin{tabular}{|c|c|c|}
\hline $\begin{array}{c}\text { Drug content in the } \\
\text { formulations }\end{array}$ & Diltiazem HCl (mg) & Etil cellulose (mg) \\
\hline$\% 25$ & 125 & 375 \\
\hline$\% 50$ & 250 & 250 \\
\hline$\% 75$ & 375 & 125 \\
\hline
\end{tabular}

\section{QUANTITATIVE DETERMINATION STUDIES IN MATRIX TABLETS}

Table 5. The results of quantitative determination studies

\begin{tabular}{|c|c|c|c|c|}
\hline Formulations & $\begin{array}{l}\text { Practical } \\
\text { drug content } \\
(\%)\end{array}$ & $\begin{array}{c}\text { Average } \\
\text { drug content } \\
(\%)\end{array}$ & $\begin{array}{c}\text { Standart } \\
\text { Deviation }\end{array}$ & $\begin{array}{c}\text { Relative } \\
\text { Srtandart } \\
\text { Deviation } \\
(\%)\end{array}$ \\
\hline \multirow{3}{*}{$\% 25$} & 24.53 & \multirow{3}{*}{24.40} & \multirow{3}{*}{0.194} & \multirow{3}{*}{0.79} \\
\hline & 24.18 & & & \\
\hline & 24.5 & & & \\
\hline \multirow{3}{*}{$\% 50$} & 46,92 & \multirow{3}{*}{46,897} & \multirow{3}{*}{0,025} & \multirow{3}{*}{0,054} \\
\hline & 46,87 & & & \\
\hline & 46,9 & & & \\
\hline \multirow{3}{*}{$\% 75$} & 69,12 & \multirow{3}{*}{69,493} & \multirow{3}{*}{0,333} & \multirow{3}{*}{0,479} \\
\hline & 69,6 & & & \\
\hline & 69,76 & & & \\
\hline
\end{tabular}

\section{HOMOGENEITY}

Table 6. The results of homogeneity studies

\begin{tabular}{|c|c|c|c|c|c|}
\hline Formulations & $\begin{array}{l}\text { Mass } \\
(\mathrm{mg})\end{array}$ & $\begin{array}{l}\text { Diltiazem } \\
\mathrm{HCl}(\mathrm{mg})\end{array}$ & $\begin{array}{c}\text { Diltiazem } \\
\mathrm{HCl}(\%)\end{array}$ & $\begin{array}{c}\text { Standart } \\
\text { Deviation }\end{array}$ & $\begin{array}{c}\text { Relative } \\
\text { Standart } \\
\text { Deviation } \\
\quad(\%)\end{array}$ \\
\hline \multirow{3}{*}{$\% 25$} & 6.0 & 1.246 & 20.77 & \multirow{3}{*}{0,251} & \multirow{3}{*}{1,199} \\
\hline & 4.5 & 0.94 & 20.88 & & \\
\hline & 2.4 & 0.51 & 21,25 & & \\
\hline \multirow{3}{*}{$\% 50$} & 5.2 & 2.077 & 39.95 & \multirow{3}{*}{0.076} & \multirow{3}{*}{0,191} \\
\hline & 3.8 & 1.520 & 40 & & \\
\hline & 4.8 & 1.925 & 40.1 & & \\
\hline \multirow{3}{*}{$\% 75$} & 2.4 & 1.60 & 66.7 & \multirow{3}{*}{0,624} & \multirow{3}{*}{0,924} \\
\hline & 4.4 & 2.916 & 66.27 & & \\
\hline & 2.4 & 1.62 & 67.5 & & \\
\hline
\end{tabular}




\section{IN VITRO RELEASE STUDY BY USING APPLYING ULTRASOUND}

The release profiles of diltiazem HCI in ultrasound applying are shown in Fig. 5-7. It was seen that ultrasound played an important role in controlling diltiazem HCI release and a pulsatile release function was observed. When the ultrasound was applied in interval time, the release of diltiazem HCI was more than without ultrasound applying. The release rates of all tablets are given in Table 7. The release rate was increased during ultrasound applying.

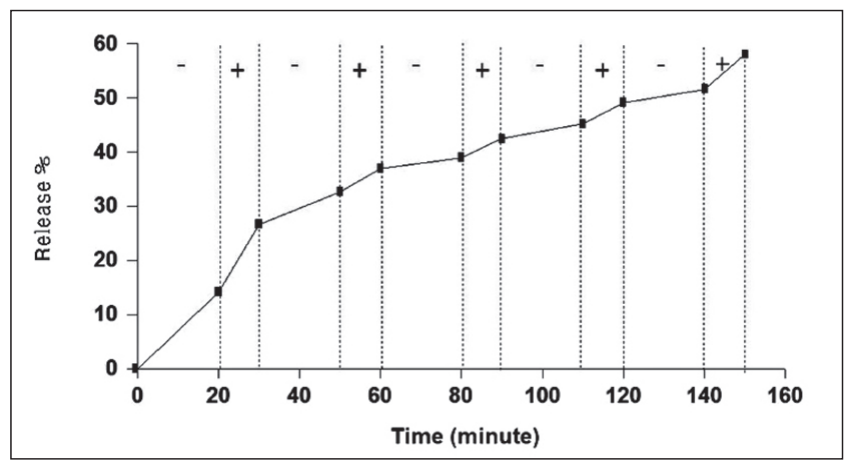

Figure 5. The release results by applying intermittently ultrasound for formulation of $25 \%$ diltiazem HCI.

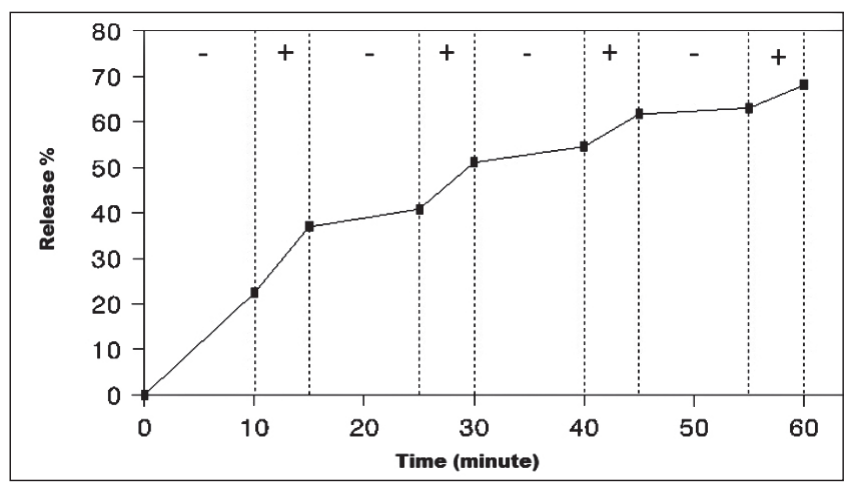

Figure 6. The release results by applying intermittently ultrasound for formulation of $50 \%$ diltiazem HCI.

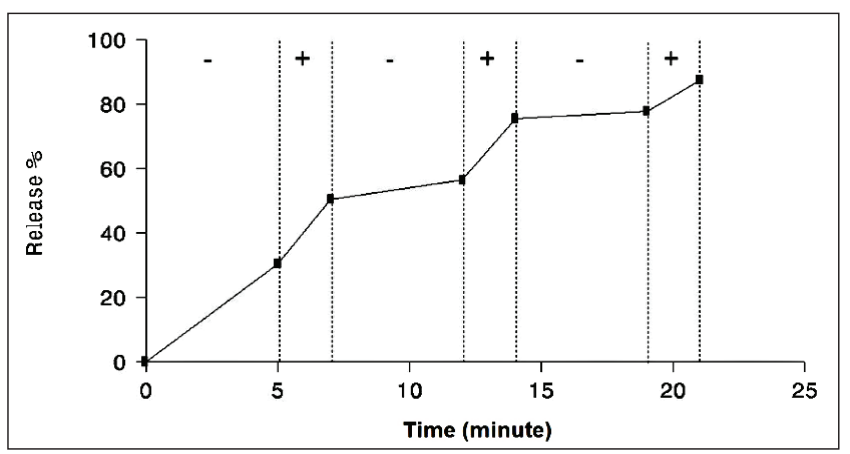

Figure 7. The release results by applying intermittently ultrasound for formulation of $75 \%$ diltiazem $\mathrm{HCI}$
Table 7 The release rates of formulations that have different drug contents by applying intermittently ultrasound.

\begin{tabular}{|c|c|c|c|}
\hline $\begin{array}{c}\text { Practical Drug Contents of } \\
\text { Formulations (\%) }\end{array}$ & $24.9 \%$ & $\mathbf{4 8 . 5} \%$ & $\mathbf{7 2 . 8 \%}$ \\
\hline $\begin{array}{c}\text { Average Release Rates (k) } \text { (min. }^{-1} \text { ) } \\
\text { (applied ultrasound) }\end{array}$ & 0.677 & 1.49 & 9.775 \\
\hline $\begin{array}{c}\text { Average Release Rates (k) }\left(\text { min. }^{-1} \text { ) }\right. \\
\text { (not applied ultrasound) }\end{array}$ & 0.120 & 0.368 & 0.825 \\
\hline
\end{tabular}

The correlation between drug contents and average release rates, which were given at Table 7, was investigated and the best correlation was found as shown in Figure 7.

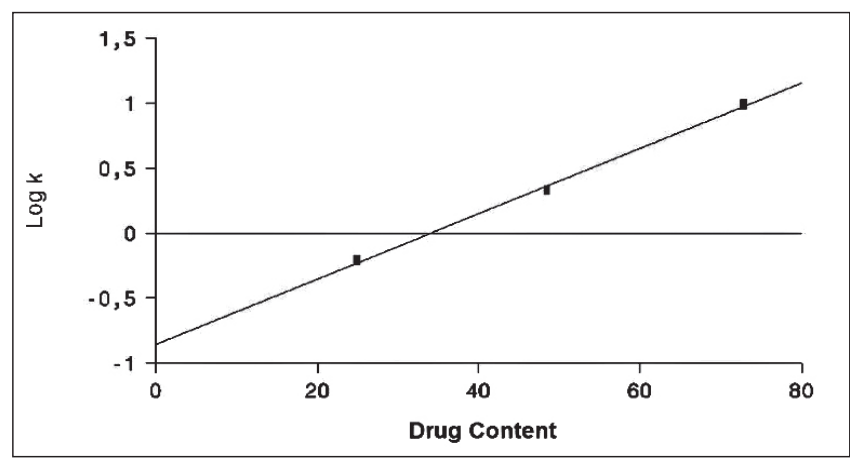

Figure 8. The correlation of release rates and drug contents by applying intermittently ultrasound.

The equation of the correlation above is:

$\log \mathrm{k}=0.00251$ drug content $-0.853 \quad$ (Equation 2)

\section{THE VALIDATION OF EQUATION}

Controlled release matrix tablets containing theoretically $15 \%$ and $35 \%$ diltiazem HCI were prepared for this study. The practical drug contents of these formulations were found $13.4 \%$ and $34.3 \%$, respectively. Ultrasound was applied intermittently. At pre-determined times determinations were made spectrophotometrically for two formulations. Release profiles were plotted as a function of time and showed in Fig 5-6. It was shown that a pulsatile release was obtained by intermittently applying ultrasound to the controlled release tablets containing drug (Figure 5-7). When ultrasound was applied, the release rates were increased definitely (Table 8). A desired formulation can be prepared with the aid of correlation between release rates and drug contents (Eq. 2) (Figure 9-10). 
Table 8. The release rates of formulations that have $34.5 \%$ and $13.4 \%$ diltiazem HCI.

\begin{tabular}{|c|c|c|c|c|}
\hline \multirow{2}{*}{$\begin{array}{c}\text { Drug Contents of } \\
\text { Farmulations (\%) }\end{array}$} & \multicolumn{2}{|c|}{ Thearetical } & \multicolumn{2}{c|}{ Practical } \\
\cline { 2 - 5 } & $34.3 \%$ & $13.4 \%$ & $34.3 \%$ & $13.4 \%$ \\
\hline $\begin{array}{c}\text { Average Relecse Rates (k) } \\
\left.\text { (min. }^{-1}\right)\end{array}$ & 1.02 & 0.304 & 1.23 & 0.405 \\
\hline
\end{tabular}

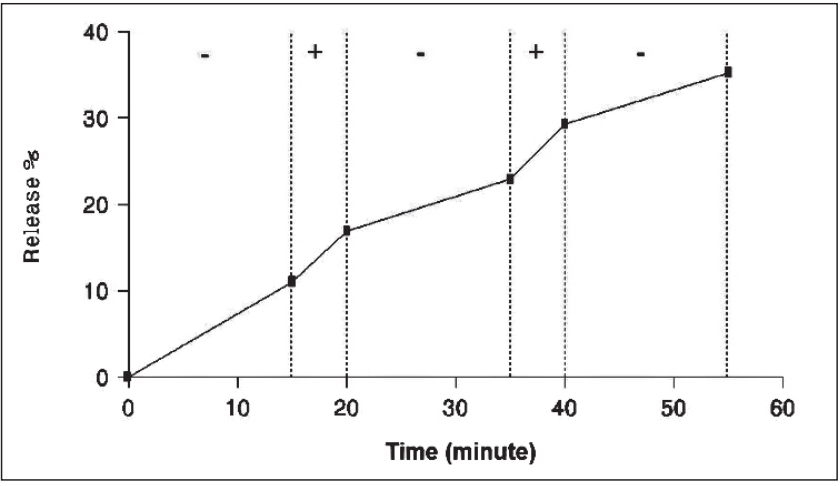

Figure 9. Applying intermittently ultrasound for formulation of $34.3 \%$ diltiazem HCI.

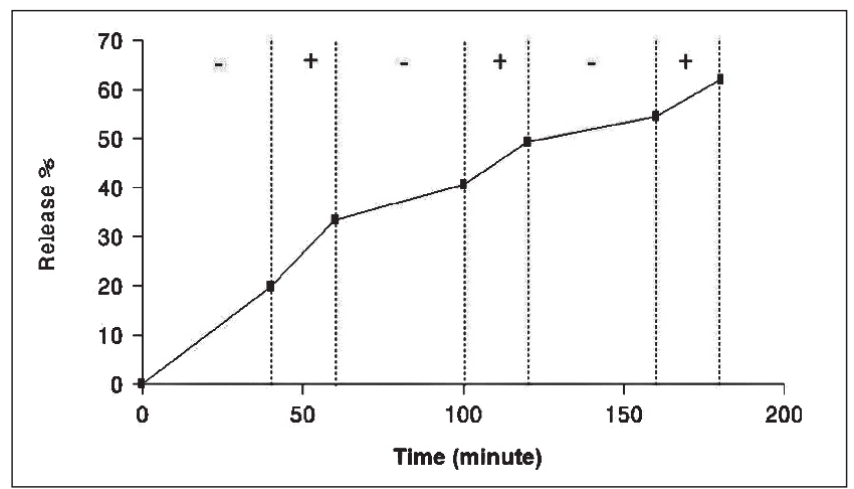

Figure 10. Applying intermittently ultrasound for formulation of $13.4 \%$ diltiazem $\mathrm{HCI}$.

\section{CONCLUSION}

Results are prove that a pulsative release system can be obtained by ultrasound from matrix systems including diltiazem HCI. Release velocity is increased considerably when ultrasound applied. This increase is about 5 times greater in formulations including $\% 25$ and $\% 50$ active substances, and it became 12 times greater in the formulations including $\% 75$ active substances. This situation verified our expectations about the effect of ultrasound on the release velocity would be much higher after a known substance value. Having the releases in zero order or at a constant velocity has been an advantageous position. Thus guessing in advance the time interval of the release of a complete drug in formulations would become possible.

By this method, the amount of the drug to be released from the delivery system which is implemented by adjusting the ultrasound application time interval can be safely utilized. This situation can be easily submitted to the doctor as a written info-note on formulation (ie. Which amount of drug dosage will be released at how many seconds ultrasound applied). Ultrasound which finds application areas mostly in hospitals nowadays along with the improved technology has become easily implicated to the patients in their houses. This draws our attention as a lately published article in a medicine periodical. FDA has approved the use of instrument Exogen which utilizes ultrasound on the treatment of fractures. In near future, patients can apply ultrasound by their selves whenever they needed, without depending on the doctors and hospitals, by this miniature ultrasound instrument. It was concluded that ultrasound may have a important effect on the release of drug and increases drug release clearly and thought that such an apparatus can also be used for obtaining a pulsatile release both at hospital and home.

\section{Pulsatil Salım Elde Edilmesi Amaciyla Ultrason Kullanımı Üzerine Bir Ön Çalışma}

\section{ÖZET}

Bu çalı̧̧mada, diltiazem hidroklorürün kontrollu salım tableti geliştirilmiştir. Kontrollü salım tabletleri diltiazem hidroklorürün değişen oranlarında etil selülozla hazırlanmış ve in vitro salım çalışmaları ultrasonik su banyosu kullanılarak gerçekleştirilmiştir. Salım sonuçlarına göre, formülasyonun ilaç içeriğini ve zamanın bir fonksiyonu olarak ilaç salımını tahmin etmede kullanılabilecek yeni bir denklem geliştirilmiştir.
Kontrollü salım dozaj şekillerinden diltiazem hidroklorürün salımına ultrasonun etkisine ilave olarak, hız sabiti ve ilaç içeriği arasındaki ilişkiler araştırılmıştır. Bu çalışmada geliştirilen denklem, farklı konsantrasyondaki diltiazem hidroklorür ile hazırlanmış formülasyonlardaki ilaç salımında ultrasonun etkisini hesaplamak amacıyla kullanılabileceğini başarılı bir şekilde göstermiştir. Ultrasonun ilaç salımında çok önemli bir etkiye sahip olduğu, ve ilaç salımını açık şekilde arttırdığı ispatlanmıştır.

Anahtar kelimeler: ultrason; kontrollü salım, pulsatil salım 


\section{REFERENCES}

1. Brownlee M, Cerami A. A glucose controlled insulin delivery system: semisynthetic insulin bound to lectin. Science 1979;206:1190-91.

2. Jeong SY, Kim SW, Holmberg DL, McRea JC. Self-regulating insulin delivery systems:III.In vivo studies. J Control Release 1985;2:143-52.

3. Kwon IC, Bae YH, Kim SW. Electrically erodible polymer gel for controlled release of drugs. Nature 1991;354:291-93.

4. Tanaka T, Nishio I, Sun ST, Ueno-Nishio S. Colapse of gels in an electric field. Science 1982;218: 467-69.

5. Grimshaw PE, Grodzinsky AJ, Yarmush ML, Yarmush DM. Dynamic membranes for membranes for protein transport: chemical and electrical control. Chem Eng Sci 1989;44:827-40.

6. Brownlee M, Cerami A. A glucose controlled insulin delivery system: semisynthetic insulin bound to lectin. Science 1979;206:1190-91.

7. Kim SW, Paii CM, Kimiko M, Seminoff AL, Holmberg DL, Gleeson JM, Wilson DE, Mack EJ. Self-regulated glycosylated insulin delivery. J Control Release 1990; 11: 193-201.

8. Hsieh DST, Langer R, Folkman J. Magnetic modulation of release of macromolecules from polymers. Proc Natl Acad Sci USA 1981;78:1863-67.

9. D'Emanuele A, Kost Y, Hill J. An investigation of the effects of ultrasound on degradable polyanhydride matrices. Macromolecules 1992;25:511- 5

10. D'Emanuele A. Responsive polymeric drug delivery systems. Meeting the patient's needs. Clin Pharmacokinet 1996;31:241- 45.

11. Kost J, Leong K, Langer R. Ultrasound- enhanced polymer degradation and release of incorporated substances. Proc Natl Acad Sci USA 1989;86:7663- 6.

12. Miyazaki S, Hou WM, Takada M. Controlled drug release by ultrasound irradiation. Chem Pharm Bull 1985;33:428-31.

13. Huang S. Liposomes in ultrasonic drug and gene delivery. Adv Drug Delivery Rev 2008;60:1167-76.

14. Frenkel V. Ultrasound mediated delivery of drugs and genes to solid tumors. Adv Drug Delivery Rev 2008;60:1193-08.
15. Mannaris C, Averkiou MA. Investigation of Microbubble Response to Long Pulses Used in Ultrasound-Enhanced Drug Delivery. Ultrasound Med Biol 2012;38:681-91.

16. Kooimana K, Böhmerb MR, Emmera M Vosa HJ, Chlonb C, Shic WT, Hallc CS, Winterb S, Schroënd K, Versluis M, Jonga N, Wamel A. Oil-filled polymer microcapsules for ultrasound-mediated delivery of lipophilic drugs. J Controll Release 2009;133: 109-18.

17. Yanga F, Wongb T, Tenga M, Liua R, Lue M, Liange H, Weie M. Focused ultrasound and interleukin-4 receptor-targeted liposomal doxorubicin for enhanced targeted drug delivery and antitumor effect in glioblastoma multiforme. J Controll Release 2012; 160:652-58.

18. Aw MS, Losic D. Ultrasound enhanced release of therapeutics from drug-releasing implants based on titania nanotube arrays. Int J Pharm 2013;443:154- 62 .

19. Zilberman M, Kraitzer A, Grinberg O, Elsner JJ. Drug-eluting medical implants. Hand Exp Pharmacol 2010;197:299-341.

20. Gulati K, Ramakrishnan S, Aw MS, Atkins GJ, Findlay DM, Losic D. Biocompatible polymer coating of titania nanotube arrays for improved drug elution and osteoblast adhesion. Acta Biomater 2012;8:449-56.

21. Aw MS, Addai-Mensah J, Losic D. Magnetic-responsive delivery of drug carriers using titania nanotube arrays. J Mater Chem 2012;22:6561-63.

22. Schlicher RK, Radhakrishna H, Tolentino TP, Apkarian RP, Zarnitsyn V, Prausnitz MR. Sonoporation by low-frequency and low-power ultrasound enhances chemotherapeutic efficacy in prostate cancer cells in vitro. Ultrasound Med Biol 2006;32:915-24.

23. Huang SL, MacDonald RC. Acoustically active liposomes for drug encapsulation and ultrasound-triggered release. Biochem Biophys Acta 2004;1665:134-41.

24. Gao ZG, Fain HD, Rapoport N. Controlled and targeted tumor chemotherapy by micellar-encapsulated drug and ultrasound. J Control Release 2005;102:203-22. 